\title{
Introduction to the Research Handbook on Law and Courts
}

Susan M. Sterett and Lee Demetrius Walker

\section{INTRODUCTION: COURTS, POWER, ACCOUNTABILITY ${ }^{1}$}

Before the worldwide spread of politics and governance through courts, scholars circulated a story about courts: they could hold central governments accountable (Easton, 1953). Since then, widespread judicialization of politics around the world has animated political reform and scholarly debate (Michel and Sikkink, 2013). The debate over when and whether courts hold central and local governments accountable keeps alive the idea that courts hold the powerful to account, serving the rule of law. Many studies of variation in courts and law take this idea as a background theoretical framework. ${ }^{2}$ That purpose of courts then sets two problems as central. First, if courts hold other powerful institutions to account, it is unclear why these institutions would allow lawsuits. The question is particularly puzzling in authoritarian regimes (Ginsburg and Moustafa, 2008; Moustafa, 2004). Attacks on courts mark authoritarianism even outside authoritarian states. The mirror problem in liberal democracies is that of understanding when and where courts hold actors to account in a way that counters what majorities seem to want. Studies of what high courts do often demonstrate how they thread this needle. Courts often rule in favor of central governments on key political issues, and in favor of more advantaged people in many others. In cases where courts would seem especially valuable for holding governments accountable - when executives claim sole authority to fight terror, conduct war, exclude asylum seekers, or manage need in emergencies - courts are often very likely to defer, or lose jurisdiction or budget or operating expenses. Alternatively, they may craft decisions that hold powerful institutions to account while allowing officials considerable discretion. If they do not hold powerful institutions to account, the fear in a liberal democracy is that courts might primarily serve the powerful's purposes of

1 Without Rebecca Postowski, this collection would not have come together, and especially not on deadline. Rebecca managed blinded peer review and encouraged authors to complete their manuscripts and revisions, sending repeated emails with unfailing good cheer. She reminded us that reviews were in, that comments from editors were needed, and that we wanted to work on the introduction and meet deadlines. Maya Sterett designed the cover photo, gamely asking questions to discern what a collection about something as broad as "law and courts" could be, so she could represent the diversity and incompleteness of promises of justice in a digital world. Rebecca and Maya and Laura Mateczun commented on earlier drafts of this introduction. We are grateful to the patient and efficient editorial team at Edward Elgar Publishing.

2 Susan Silbey (2005: 358) argued that studies of the politics of law needed to take on the creation of consensus at a time of war and polarization when governing is in the hands of wealthy elites. Since she wrote, wars continue, polarization has deepened, authoritarianism has more powerful and vocal advocates, and the electronic media she references have spread. This introduction will take the contests over what courts are for in the context Silbey described. 


\section{Research handbook on law and courts}

excluding and punishing. In recent years, disputes over asylum seeking, citizenship and rights for disadvantaged people have highlighted questions about what courts do. Digital technologies can amplify surveillance and bring more people and more activities into the enforcement that facilitates punishment and exclusion in court. Each of the chapters in this collection empirically explores where and how courts interpret rights and power, and how courts work in a political field. When read together, many of the chapters in this collection demonstrate that ideas circulate across courts and litigants, so no one institution or set of actors originates legal claims. If courts can hold power to account, making claims, and circulating and amplifying ideas serves the purpose more than the outcomes in courts themselves.

The authoritarianism resurgent in many countries has included suspicion of courts: that independent courts, when doing their ordinary jobs, act illegitimately against the popular will. Authoritarianism has brought with it claims to emergency, a corollary to war in the claim to need to act outside constitutional guarantees (in Turkey: Kingsley, 2017), or dismiss judges (in Poland: Santora, 2017), or claim judges are wrong for deciding asylum seeking cases in the United States (Brennan Center, 2017). In Europe and the United States, regulating belonging has proven to be a central case for controversies over courts' work (Sterett, 2016). Budget cuts or shutting down operations also threaten domestic courts. At the same time, increasing surveillance through digital records feeds the courts' oppressive work of excluding and punishing. The paradox that recent authoritarian attacks on courts reveal in conjunction with scholarship on courts is the persistent promise that courts can hold power to account, even if they often fail to do so.

The ideal that courts check power when no other institution will, even when courts disappoint, contributes to the continued pull of going to court. When resources and opportunities make pursuing claims possible, the ideal that courts hold the powerful to account comes to life (Epp, 1998). Less visible appeals and implementation that limit the significance of a decision come later. A long timeline, fading attention, and a lack of options contribute to the persistence of the idea that courts can hold power to account and that the countermajoritarian problem is the central problem of courts in governance in liberal democracies. Scholars and news reporting amplify cases where courts do call power to account (Fisher, 2013; Hamlin, 2016; Wines, 2019). Constitutional courts and supranational courts participate in high politics disputes over constitutional principle, even if decisions do not lead to political transformation (Kenney, Reisinger and Reitz, 1999). In structuring dialogue across institutions and with civil society groups, courts may sometimes reinforce democracy, rather than acting as a countermajoritarian force (Cichowski, 2007). Even losing cases may have spillovers that civil society groups value (Arrington, 2019). "[S]ilicon and electromagnetic connections" (Silbey, 2005: 358) solidify debates about courts, as they do those about other political institutions. Now, these connections also intensify surveillance in legal processes.

The chapters in this collection bring to light the proliferation of courts and multiple meanings, beyond the high court that is often the center of attention in studies of judicialization of politics. The process and people, beyond the outcomes, are part of judicialization. Laws and the courts that interpret them take complaints, decide motions, admit evidence, issue preliminary injunctions, and decide which texts to reference to authorize their decision. They produce documents. People and processes craft the world into "legalfacts" (Silbey and Cavicchi, 2005), or facts that are inextricable from the law. 
Setting the countermajoritarian problem as the central problem of how courts act draws on a limited set of conflicts. Direct confrontation is also not the main way institutions exercise power; setting the ground for decisions and relying on existing categories shapes the questions anyone can ask. Law, including in courts, shapes governance problems by working with particular language and processes (Mertz, 2007; Latour, 2009), sometimes setting problems for other institutions. Courts, both general jurisdiction and administrative, enforce ordinary legislation and administrative rules (Hamlin, 2011). Sometimes legislatures and executives respond (Kretsedemas, 2012; Melnick, 1994). They can manage courts' jurisdiction to exclude some cases, change legal standards, or speed up how the courts handle cases (Sterett, 1997; Soennecken, 2015; Hamlin, 2014).

The chapters in this collection complicate stories of judicialization based in high courts, constitutions, and directly confronting executives. Read together, the chapters show that legal ideas circulate through the litigants who borrow claims from courts, the high courts that limit themselves before executives, and the lower courts that borrow from litigants and shape arguments for higher courts,. If courts matter in holding executives accountable, their work depends on the proliferation of networks of courts, actors, and arguments that do not work in a unitary hierarchy (Epp, 1998), as much as on the willingness of courts to confront national executives on core issues. Courts govern via clerks, lower courts, litigants, networks of practice and citation across courts, institutional interaction, and public perception (Walker, 2016). Electronic media publicize what courts do, make the work immediately accessible from desktops, and proliferate commentary, also contributing to a "governance by courts" effect.

The rest of this introduction outlines the book's sections.

\section{COURTS AND POLITICAL ACCOUNTABILITY}

The aftermath of authoritarian rule in countries around the world made the question of whether the courts could hold executives accountable a matter of practical political concern, for governments as well as for domestic and transnational human rights activists. Judicial independence would increase judicial capacity to impose accountability on executives (Ginsburg and Melton, 2014; Helmke, 2012; Helmke and Rios-Figueroa, 2014; Hilbink, 2007; Kapiszewski, Silverstein and Kagan, 2013). Courts would be crucial to holding other branches accountable, which was necessary to the rule of law (O'Donnell 1998; 2001). Politically, the rule of law as imposed by courts could be in tension with the equally important wish for a justice system that responded to the popular will in democratizing countries (Diala, this collection).

The chapters in this section address the claim that courts impose accountability on central executives, where executives claim they represent the will of the people. Topics include political issues that are key to central executives: climate change, international human rights law, domestic criminal law, and war. Political accountability includes the interplay between: (1) international structures and domestic actors (Meernik); (2) the executive and courts and the law (Johnson, Schorpp); (3) courts and mass publics (Hilson, Ponce).

First, domestic political actors constrain international courts, as Meernik argues, even when international courts represent themselves as holding individuals accountable for violating international human rights. Domestic actors are responsible for referring criminal 


\section{Research handbook on law and courts}

cases to international courts. Without referrals, they cannot enforce international human rights. Second, executives often control budgets and drive political processes through budgets' public criticism, or responsibility for implementing decisions. In international dispute settlement, advantages accrue to experienced participants (Conti, 2010), just as they do in domestic courts.

Executives limit courts by anticipation. Gbemende Johnson argues that judges know executives control the implementation and the enforcement of the law, so they defer to the executive rather than ask for the impossible. Johnson argues that courts are most likely to defer to the central executive in foreign affairs, including treaties, trade, immigration, and war powers.

If courts defer on issues where they expect that executives will claim popular support, they are especially likely to defer during war. Executives use war to mobilize mass support. Their claim to unitary power in war could spill over well beyond the war powers discussed by Johnson. Susanne Schorpp explores the spillover beyond war powers in case outcomes by comparing high courts in Canada, the United Kingdom, and the United States during the War on Terror in the post-9/11 world. She finds that courts in all three countries rule against the government at the same rate during periods of peace or war.

The belief that courts might rule more often with executives in wartime depends on a belief that war and other emergencies depend on a unitary executive will, and are therefore lawless. A provocative counterpoint holds that bureaucratic states operate through law-like systems, possibly including courts. Rather than wars and emergencies leading to the absence of law in part via attacks on courts, emergency actions and decisions in wartime lead to "hyperlegality": a proliferation of documents, cases, guidelines, and interpretations of all of them (Hussain, 2007), which can promote surveillance, policing, uncertainty, and judicial deference. Emergencies, war, terrorism, and the hope of holding human rights violators to account thread through individual bureaucratic legal processes (Lokaneeta, 2018).

Justice system structures contribute to circulating ideas and experiences that reinforce common sense. Chris Hilson argues that twenty-first century populist authoritarianism has affected outcomes concerning climate change in the United States. Advocates for gaining popular support for checking climate change have focused on narrating problems, with stories that have characters and plots with beginnings, middles, and ends. Hilson argues that focusing on stories to persuade mass publics risks undermining the expertise required to manage climate change.

Courts can participate in militarization that executives support, feeding into law as oppressive, as in the international war on drugs in Latin America. Aldo Ponce argues that drug policy contributes to greater violence, and the perception of drugs as a major problem. He argues that negative spillovers from aggressive enforcement of drug policy can erode trust in the justice system. Aggressive enforcement is popular and can lead to support for courts. However, it promotes greater victimization and thereby mistrust of the justice system. Ponce's chapter demonstrates the importance of an interactive approach to studying courts, understanding them as participants with others in interpreting law. 


\section{JUDICIAL PROCESS}

The chapters in this section shift from how courts hold executives accountable to horizontal relationships across courts, and to courts' internal processes. Courts vary in how they borrow from each other, and how they respond to caseloads. Decisions from one set of courts are embedded in texts available for litigants and other courts to borrow. In addition, judging produces papers and decisions on motions along the way to an outcome, documenting the case and the work of courts. Scholarship on documents, how they are organized, and the knowledge they carry - and who they carry it to - offers insights on how institutions create and certify legal truth (Geslin and Hertz, 2005; Riles, 2006).

Judicial independence is a pillar of the ideal that courts can hold the powerful to account. Measures of judicial independence often focus on independence from the central executive, driven by the normative question of how courts enforce the law while also according with democratic majorities. Measures of independence can include constitutional structures, or how legislatures control jurisdiction. Rios-Figueroa examines internal independence, or independence from supervision within the court hierarchy rather than from the executive. Dilemmas of legitimacy depend on taking for granted that judges do their jobs, which in turn requires some forms of supervision. Rios-Figueroa argues when independence means no supervision, courts can be open to corruption.

Supervision internal to the judicial system includes reasoning through precedent, which attorneys use in common law countries to build persuasive documents that will define the scope of judicial decisions. The story that legal scholarship tells to justify studying high courts is that precedent binds courts in a hierarchy, and high courts sit atop the hierarchy. However, precedent and ideas about the law circulate among judges, lawyers, law professors, and commentators. The language in the written arguments, or briefs, used by litigants before the United States Supreme Court can influence the Court. Schoeneherr and Black argue this point concerning the Establishment Clause of the US Constitution, which prohibits the United States government from establishing a religion. On the one hand, of course the litigants should influence the Court: what else would be the point of drafting arguments? On the other hand, Schoeneherr and Black's work shows how law circulates, so decisions do not flow downward in a hierarchy. Precedent and the principles that courts articulate presume that changing the principles changes the law. Courts can also impose accountability via the accumulation of the weight of cases rather than one grand principled decision. Tiede and Achury argue that the legal writ amparo, a writ widely used in Latin America, creates an easier route to the courts for individuals claiming wrongdoing. The accumulation of amparo cases in Peru led to new law in the area of pensions, and in controversial areas including gay marriage. They also argue that the cumulation of cases can signal something is wrong with how governments respond to the citizenry.

Also shaping what judges decide is how the processes and people before them have built the facts that allow them to decide cases. Judges make decisions on the facts before them. The judicial process builds those facts, with nationally distinctive ways of certifying something as a fact to be legally recognized. In that process, multiple ways of telling stories about what happened become fixed. What the judicial process turns into uncontestable facts then guides judges to deciding responsibility. These processes are crucial, and stories of particular compelling complex cases often turn on contests over documenting 
facts (see e.g. Schuck, 1987). Yet assessing what judges do seldom takes into account the court-driven process of certifying facts. Mayur Suresh closely follows a terrorism case from India, describing how processes lasting many years allow the files to become the facts of the case. The context of terrorism, and the global war on terror, influences how legal processes assemble documents and processes.

Finally, the countermajoritarian problem also becomes more complex when legislatures can return to a question to revise what a court has decided. Well-mobilized groups can prevent a legislature from changing what a court has decided. Jonathan Parent examines court and legislature interactions in the context of Canadian reproductive rights. Parent argues that institutions adapt, and the legislature can benefit by taking credit for what courts decide.

The physical spaces of courts represent accountability differently. Robson and Branco take this point to contrast the fascist representation of judging and the state in Portugal with bureaucratic courts handling daily troubles in a late bureaucratic welfare state.

Legal ideas circulate via outcomes, processes, and interactions across institutions. In recent years, advocates, scholars and public officials have turned to descriptive representativeness of the judiciary as a legal idea that matters..

\section{DIVERSITY, LAW AND COURTS}

Law is a professional structure that could guide officials, including judges. The training judges gain in the law aspires to teaching a technique. The technique includes interpreting texts that transcend an interpreter's ethnic or gender identity, whether in common law or civil law jurisdictions. The disembodied, depersonalized law views impersonal texts. That transcendent aspiration has long worked within domination and exclusion. Critiques of law have included critiques of the profession as excluding and discriminatory. Movements for equality made the claim that judges' gender and race were irrelevant less plausible. If men were the best, and judging required the best, not representing women was irrelevant, or a pity, but impossible to remedy. Movements for gender equality put that argument to rest. Putting judges' gender on the agenda (Kenney, 2013) could threaten to require something additional of new judges who were not members of dominant groups. In the United Kingdom, constitutional reform in the 1990s included considering appointing women; modern countries included women in professions whether or not they decided differently from the men (Kenney, 2013). Along with other constitutional reforms, appointing women was a way to respond to the anti-constitutionalism of the 1980s in the United Kingdom's government. In Europe, legal professionals monitor judicial appointments to advocate for greater diversity, as Ulrike Schultz discusses.

In the United States, as women joined the bench, first studies asked how demographic difference made a difference. The first thing to study in social science within the United States was whether women voted differently from men who were judges. This approach bracketed off other reasons for inclusion: equal opportunity, or the political significance of appointments (Kenney, 2013).

Within the United States, a long history of studying differences in voting by party of the official appointing a judge offered a model for studying variation by gender. The question of voting differences has applied less well to judging in other countries, not least 
because of an ethic of collective decision making even with individual votes. Furthermore, it turned away from professional training and experience as key to what judges did. In the United Kingdom, the historically institutionally conservative legal profession aligned with the Conservative Party; critics argued that depersonalized and disembodied meant Conservative and male (Sterett, 1997; Kenney, 2013). The work process and the symbolic significance of who judges were dropped out of research questions concerning judges, outcomes in cases, and partisan differences.

Descriptive representation has been built into courts outside of race and gender without significant controversy or debate about why it is necessary. Race and gender diversity could join geographical descriptive representation, as Sally Kenney has argued (2013). The Court of Justice of the European Union and the European Court of Human Rights are supranational courts designed to nationally representative. These courts are complex institutions that rely on the power of persuasion. In this collection, writers reach beyond the politics of outcomes to discuss theoretical justifications and some empirical results concerning descriptive representation.

As Moyer; Escobar-Lemmon and colleagues; Dawuni and Masengu; and Means and colleagues all demonstrate, the reasons for caring about diversity in judging reach well beyond outcomes in cases where gender or race is particularly salient. Shared professional training need not lead to differences in judgment. Some judges have viewed the argument that gender matters because of difference with some suspicion; it denigrates professional accomplishments by asking that people rely on different to justify a seat on a court (Kenney, 2013).

Escobar-Lemmon and colleagues search for patterns in variation in appointing women to high courts. In addition to appointments, Moyer and others assess how gender might matter in work practices. The chapters also synthesize the research that has been done in differences in outcomes by gender, largely based in the United States.

Whatever the outcome, in the common law system judges give reasons for their decisions. The reasons can demonstrate commitments concerning gender, race, and identity. After giving an overview of changes in appointments to the federal courts from the United States Obama administration to the Trump administration, Taneisha Means and her coauthors closely read a judicial opinion in light of how the justices reflect on their biographies. Judicial biography in the United States has been a lens to interpret how judges understand their craft (Kalman, 1990). Memoir has met judicial biography in this self-conscious era.

Judging is a different enterprise cross-nationally. Not only do differences in outcomes by gender not capture how gender is salient, given the homogeneity of professional training. The image of judging and power differs, allowing differences in imagined gender. In the United States, where judges are imagined to be very powerful, judging is likely to be interpreted as a male enterprise. In contrast, in France, and possibly other civil law countries, judging's image is more one of bureaucratic service under rules (Remiche, 2014).

The chapters in this section synthesize both diversity by gender on courts around the world, and research on why it matters. 


\section{COURTS THAT DO MOST OF THE WORK: SUBNATIONAL COURTS}

The theoretical starting point for courts and accountability has been that high courts are principals. The empirical, political, and theoretical puzzle has been how they can control the agents charged with doing the work of the principal. The agents are the lower level courts; in a hierarchical model, they look to the upper level courts for what they should do. Much of the work of courts takes place at the regional, provincial, or state level in federal systems including the United States, Canada, Germany, and Mexico, or at the domestic level regarding European law (Conant, 2002). The language of principals and agents has been especially significant outside of legal commentary. Social sciences sometimes reframe how lawyers talk about courts to use the language of political institutions. Social scientists have referenced the significance of the same elements shaping decisions that have been highlighted by legal practitioners and theorists: case facts (George and Epstein, 1992), precedent (Knight and Epstein, 1996), oral arguments (Johnson, 2004), amicus or friend of the court or intervenor briefs (Collins, Corley and Hamner, 2015; Cichowski, 2016), judicial selection processes (Hall and Bonneau, 2009), and state Supreme Court decision making (Songer and Crews-Meyer, 2000; Benesh and Martinek, 2002).

However, agents are multiple in systems where civil groups bring cases to court and judges borrow from each other. How to tell who is acting as though they are in charge? Why assume that the highest level courts have the upper hand? One measure of who takes the initiative is the language used. If courts adopt language from civil society groups, then perhaps they lead. If lower courts use language first and the upper level courts later borrow words from them, perhaps the lower courts lead. The institutions develop language jointly: the institutionally sensible decision by civil society groups and lower level courts would be to use language close to what courts have already used, or that helps with a problem or puzzle embedded in earlier decisions. In this collection, Kassow, as well as Bowie and Savchak, evaluate principals and agents in courts by evaluating language.

Studies in this section expand beyond the usual civil rights to look at tort or personal injury law in an American state (Dumas), public health and environmental law (Da Ros and Ingram, Muñoz and Moya), and domestic violence (Moult). Personal injury law in the United States is more available than in other countries, where social welfare state programs sometimes meet the need for disability or medical care, or where states have chosen to deny court-based strategies for accountability. Each area draws into question what centering studies of courts on high courts and counter-majoritarian difficulties leaves out.

Organizing comparison systematically risks either erasing local specificity or becoming so lost in specificity that accretion of detail substitutes for analysis (Shapiro, 1981). Building from the specific case of Brazil, Da Ros and Ingram propose four grounds for analyzing courts. They argue that courts vary in: (1) empowerment; (2) how they are activated, or how law is mobilized; (3) what judges do; (4) how cases are meaningful outside the court. Da Ros and Ingram explore variation along these dimensions in public health and environmental policy in Brazil.

Language in opinions can flow from lower courts to higher, countering the image of courts as working in a top down hierarchy. Bowie and Savchak argue that lower level courts influence the development of law by using language higher level courts adopt in the American states. The same insight applies to the United States Supreme Court. Those 
making claims to state Supreme Courts craft arguments borrowing from the United States Supreme Court. These findings lead to describing the politics of the law in the courts as a network of arguments that circulate among participants.

If ideas about what legal arguments are effective circulate among legal professionals, litigants can make their best guesses about what arguments work, and when to take a case. Appellate courts inform decisions about cases to take and what to appeal, having issued opinions that show which arguments work. Tao Dumas revisits questions about whether and when the haves come out ahead in litigating the kinds of cases that matter in daily life: personal injuries. Since these cases in state court can be hard to find, partially accounting for how understudied they are, Dumas assembles cases from a report of jury verdicts. Like others before her, Dumas finds that despite the image of the United States as filled with people who routinely litigate, many people do not file suit. Even when they do, wealthy repeat players prove more likely to appeal, and appeal courts in turn favor defendants who appeal.

Turning to less visible courts and less prominent cases invites turning to other problems in daily life, other courts, and other gatekeepers. Clerks have the first line of responsibility for shaping a problem into a case and developing the 'legal facts', the facts of daily life so imbued with law that it is impossible to separate law and fact (Silbey and Cavicchi, 2005). Kelley Moult argues that South African court clerks in domestic violence cases are central to changing people and their problems into a case. How lower courts handle gender-based violence is in turn integral to assessments of whether constitutions hold power to account. Without equity and safety, people perceive the promise that a constitution in South Africa would transform the society (Diala, this collection) as a false hope (Judge and Smythe, forthcoming).

Political gaps make multilevel alliances possible, also complicating the story that courts impose their will on democratic majorities. Luz Muñoz and David Moya take the case of environmental regulation in Spain to argue that the pull of supranational factors (EU) at one end and decentralization (regional authorities) at the other opens a space for nongovernmental environmental advocates to Europeanize local environmental law in Spain. Muñoz and Moya's chapter establishes multilevel governance (supranational, domestic, and regional) and NGO organizational attributes internationalize outcomes in environmental law.

\section{COURTS, INCLUSION, BELONGING}

Fears in wealthy countries about who does and who does not belong animate authoritarianism, evidenced by controversies in recent years over asylum seekers, which were preceded in many European states by controversies over immigration from former colonies. Brexit's appeal was in part the aspiration of marking who belongs and who does not, organized into orderly national categories, an impulse that in turn is continuous with the history of empire (Hussin, 2007; Massoud, 2013; Mishra, 2019), including policing members of the Commonwealth who came earlier. These lines have fed court cases. Appeals of individual decisions, made under domestic laws, come to court. The demands for labor in the United States and in Germany have been fodder for court cases. When people have emigrated to work, they have not had full rights of settlement or citizenship. 
People have fought losses, when rulers had not thought the laborers they invited would come with families and claims to stay. Indigenous people have also fought back against destruction with rights claims (Hamilton, 2011). Asylum seeking throughout the world in the twenty-first century has placed administrative courts and their caseloads at the heart of public debate. Policing inclusion in the interest of a theoretically described sovereignty that does not accord well with international commitments and joint histories of dominance and subordination has been central to the work of courts (Sterett, 2016). Therefore, this section includes chapters that compare regulating inclusion. Lisa Conant and her coauthors synthesize cross-national regulations of inclusion in light of resurgent authoritarianism.

Courts don't enact independence in the abstract. They do so about specific issues, often managing case level decisions where legislatures have built in complexity or selfcontradiction, where people with access to lawyering have wrangled their problems to fit into legal categories. Theories often developed from the United States concerning the mobilization of law, or the motivations of judges, or differences in judging by gender, have often drawn from areas particularly salient to political debate. From these areas scholars have developed general theories concerning the resources required to mobilize law, how organizations deflect or incorporate legal decisions, and how judges' decisions demonstrate their political commitments. Civil rights and civil liberties, especially concerning liberties that have been contentious in the United States, have often been the focus of studies concerning judicial motivations. These studies reflected a postwar elite consensus concerning the most important issues in the United States. That postwar consensus from scholars based in the United States did not consider the centrality of governing indigenous peoples (Hamilton, 2011; Richland, 2005) or colonialism (Hussin, 2007), including migration from the former colonies in postcolonial societies (Sterett, 1997).

States have governed violently and incompletely even with courts, however much judging implies conflict resolution. Courts have decided individual case level decisions - of asylum seekers who are trying to gain permission to stay, for example - and constitutional principles concerning control of land, the status of treaties, access to rights, and the regulation of child placement. The latter has been a matter of bitter dispute in settler countries with histories of brutality to indigenous peoples, including Australia, Canada, and the United States. Chapters by Rebecca Reid and Todd Curry (examining indigenous/common-law conflicts in the United States) and Kati Nieminen (examining indigenous rights in Finland) directly address matters concerning indigenous peoples' inclusion.

Courts and the legislatures and executives that govern them have used the ordinary technical doctrines and organizational strategies available to them, and lawyers have tried to contest them (Hamlin, 2014; Sterett, 1997). In this volume, Audrey Comstock shows that domestic legal and political actors can also use international conventions to address issues of belonging and inclusion. 


\section{DIGITIZATION OF LAW AND COURTS: RESEARCH AND PRACTICES}

People and many governments increasingly rely on digital records. Experiences of governing, including through courts, involve virtual experiences at a computer screen. Distant courts and their physical spaces are accessible through visualizations. Court records that are public become available anywhere there is an internet connection, not only in the physical space of a court.

This section takes on that change in two ways.

First, governments have used open data initiatives to promise to hold governments accountable (Ruppert, 2015). The goal of democratizing data, as the advocates for open data claim, can bring along exposing people to greater collateral damage from legal processes when arrest and court records are available online. As Sarah Lageson argues in her chapter in this section, in the United States, the decision to share can be punitive. It is not inevitable. Local governments put disclaimers on their websites about the accuracy of their records, but it is easy for readers to take records on websites to be accurate. In the criminal justice system, public records, whether they are accurate or not, can be monetized, and they are. Websites that monetize public information promise to reveal arrests and criminal convictions (Lageson, 2015). Digital records amplify penalties in the criminal justice system because they do not go away. In contrast, Europe has instituted a right to be forgotten, or taken out of search engine results. People's digital traces, now called data, are sometimes given the name "the new oil," or the basis for new economic growth. Just as with the old oil, fortunes are built on appropriating publicly produced goods, and a lack of regulation permits negative externalities with costs in surveillance borne by those least able to bear them.

Digital traces and digital records are available for use in legal processes. The digital information that comes with living lives online - through fitness tracker devices, through internet searches and social media, through direct to consumer genetic testing - is available to the legal system to use as data in new ways as well. Andelka Phillips's chapter discusses what it means when "all your data can be used against you."

Second, researchers have been transforming court records into data easily shared across time and space to build research agendas and communities. Meg Leta Ambrose has named this process across forms of knowledge "datafication" (Ambrose, 2014: 10-11). She relies on Ian Gould to define data as "a representation of facts or ideas in a formalized manner capable of being communicated or manipulated by some process" (Ambrose, 2014: 11). Chapters in this section consider what these changes to research mean, and explain the work and judgment that goes into building databases.

In big data analytics, the work of making records or digital traces into data is "banished" (Ruppert, 2015), or "black boxed" (Pasquale, 2015). In scholarship, funding agencies press for data access (ESRC, n.d.; NSF, n.d.) and some professional associations ask for work that allows sharing across platforms. Sharing data is to serve multiple purposes, including teaching and outreach, as well as to make it more possible to replicate scholarship. The epistemological assumptions underlying the belief that replication should be easily done when data are shared are currently a matter of hot debate within the social sciences. Sometimes that debate is captured as a difference between quantitative data, sometimes assumed to be easily shared, and sensitive interview data that is not. However, 
that debate misses how much that first, sharing work product without having built trust is difficult, and second, that regulations protect some digitized data from sharing because they are also sensitive (Sterett, 2018).

What gains less debate are the work practices in building databases. Transformations are time consuming. Elizabeth Chrun and Rachel Cichowski, and Paul Collins and his coauthor Lori Ringhand, describe the digital databases they have built for law and courts research. They explain what the databases include, the work processes for building them, and the decisions they had to make. Newly constructed electronic databases allow new forms of visualizing judicial decisions. If research transparency is valuable, the work it takes to build the databases should be available too. Requiring data to be shared turns scholarship toward records easily shared, and away from questions where they are not. The requirement to build databases can become another way to guide research toward those who have greater resources. Databases can reshape who knows, and what kind of contextual knowledge is necessary before one begins to interpret.

Wedeking turns from the database construction reflected upon by Chrun and Cichowski and Collins and Ringhand to the automated analysis that computing power allows. Wedeking, and Schoenherr and Black answer critiques of automated textual analysis that hold that human beings read texts better than computers do because people read holistically. Wedeking argues that they are complementary skills. Automated textual analysis can analyze more texts. People can read for nuance. He would argue that holistic, nuanced reading is not always necessary. Wedeking closes his chapter with an analogy with policing. He argues that beat cops and surveillance from a distance reveal different kinds of information, and he argues both can be necessary. To follow his policing analogy, largescale surveillance brings more people into the scope of policing more quickly. The greater risk for more people also undermine expertise-based reforms of policing that could allow closer, less punitive connection with communities (Brayne, 2017).

Data digitization raises both privacy and equality concerns, as Lageson explains. In research, Institutional Review Boards take responsibility for people's privacy, as Wedeking mentions briefly. Digital records transform research work in ways not readily accounted for in traditional human subjects review. Harms were once individual, resulting from intervening in individual lives. Harm now can come well after data are collected, and harm can come from data people did not know were collected. Sometimes data can put people at legal risk. Not all harms are easy to name: public records can allow people's identities to be revealed when they wanted to keep them hidden (Metcalf and Crawford, 2016). Regulators have found valuing the harm in data breaches difficult, since financial damage is in the future. Given the money that businesses make from collecting information, fines do not regulate effectively.

\section{CONCLUSION}

High courts do not exhaust judicialization. They do not manage the majority of cases. Officials implement law, anticipating legal changes and what courts might do. Officials also shape legal complaints to conform to legal categories. Ideas about what the law is circulate among courts and litigants. Circulating ideas and amplifying news about the courts embed the idea of courts as a check on others' power. Resurgence of authori- 
tarianism in multiple countries highlights the fragility of a belief in courts as a check on power.

This collection also contributes to expanding what counts as the subject matter for accountability in courts. Administrative systems and lower courts decide crucial problems for people, including asylum status, migration, environmental responsibility, and domestic violence. Rather than relying on the questions at the heart of how legal theorists have described institutional relationships such as judicial independence or the rule of law, the chapters in this collection contribute to telling a complex set of stories.

\section{REFERENCES}

Ambrose, Meg Leta. 2014. Lessons from the avalanche of numbers: Big data in historical perspective. I/S Draft: $1-71$.

Arrington, Celeste. 2019. The Mechanisms behind Litigation's 'Radiating Effects': Historical Grievances against Japan. Law and Society Review 53(1): 6-40.

Benesh, Sara C. and Wendy L. Martinek. 2002. State Supreme Court Decision Making in Confession Cases. Justice System Journal 23(1): 109-33.

Brayne, Sarah. 2017. Big Data Surveillance: The Case of Policing. American Sociological Review 82(5): 977-1008.

Brennan Center for Justice. 2017. In His Own Words: The President's Attacks on the Courts. June 5. www. brennancenter.org/analysis/his-own-words-presidents-attacks-courts Accessed January 16, 2019.

Brennan Center for Justice. 2018. Courts under Pressure: Judicial Independence and Rule of Law in the Trump Era. April 30. www.brennancenter.org/analysis/courts-under-pressure-judicial-independence-and-rule-lawtrump-era-0. Accessed January 16, 2019.

Cichowski, Rachel A. 2007. The European Court and Civil Society: Litigation, Mobilization and Governance. New York: Cambridge University Press.

Collins, Paul M., Jr, Pamela C. Corley, and Jesse Hamner. 2015. The Influence of Amicus Curiae Briefs on U.S. Supreme Court Opinion Content. Law and Society Review 49(4): 917-44.

Conant, Lisa. 2002. Justice Contained. Ithaca, NY: Cornell University Press.

Conti, Joseph A. 2010. Between Law and Diplomacy: The Social Context of Disputing at the World Trade Organization. Palo Alto, CA: Stanford University Press.

Corley, Pamela C., Paul M. Collins, Jr, and Bryan Calvin. 2011. 'Lower Court Influence on U.S. Supreme Court Opinion Content.' Journal of Politics 73(1): 31-44.

Easton, David. 1953. The Political System: An Inquiry into the State of Political Science. Chicago: University of Chicago Press.

Economic and Social Research Council (ESRC) n.d. Research Data Policy. https://esrc.ukri.org/funding/ guidance-for-grant-holders/research-data-policy/ Accessed November 26, 2018.

Epp, Charles R. 1998. The Rights Revolution: Lawyers, Activists, and Supreme Courts in Comparative Perspective. Chicago: University of Chicago Press.

Fisher, Elizabeth. 2013. Climate Change Litigation, Obsession and Expertise: Reflecting on the Scholarly Response to Massachusetts v. EPA. Law and Policy 35(3) (07/01; 2018/12): 236-60.

Gardner, James A. 2008. In Search of Sub-National Constitutionalism. European Constitutionalism Law Review 4(2): 325-43.

George, Tracey E., and Lee Epstein. 1992. On the Nature of Supreme Court Decision Making. American Political Science Review 86(2): 323-37.

Geslin, Philippe, and Hertz, Ellen. 2005. Public International Indigenes. In Bruno Latour and Peter Weibel, eds, Making Things Public: Atmospheres of Democracy. Cambridge, MA: The MIT Press, 566-74.

Ginsburg, Tom, and James Melton. 2014. Does De Jure Independence Really Matter? A Reevaluation of Explanations for Judicial Independence. Journal of Law and Courts 2(2): 187-217.

Ginsburg, Tom, and Tamir Moustafa. 2008. Rule by Law: The Politics of Courts in Authoritarian Regimes. New York: Cambridge University Press.

Hall, Melinda Gann, and Chris W. Bonneau. 2009. In Defense of Judicial Elections. New York: Routledge.

Hamilton, Jennifer. 2011. Indigeneity in the Courtroom: Law, Culture, and the Production of Difference in North American Courts. New York: Routledge.

Hamlin, Rebecca. 2014. Let Me Be a Refugee. New York: Oxford University Press.

Hamlin, Rebecca. 2016. Foreign Criminals, the Human Rights Act, and the New Constitutional Politics of the United Kingdom. Journal of Law and Courts 4(2): 437-61. 


\section{Research handbook on law and courts}

Helmke, Gretchen. 2012. Courts under Constraints: Judges, Generals and Presidents in Argentina. New York: Cambridge University Press.

Helmke, Gretchen, and Julio Rios-Figueroa. 2014. Courts in Latin America. New York: Cambridge University Press.

Hilbink, Lisa. 2007. Judges beyond Politics in Democracy and Dictatorship: Lessons from Chile. Cambridge: Cambridge University Press.

Hirschl, Ran. 2004. Towards Juristocracy: The Origins and Consequences of the New Constitutionalism. Cambridge, MA: Harvard University Press.

Hussain, Nasser. 2007. Beyond Norm and Exception: Guantanamo. Critical Inquiry (Summer): 734-53.

Hussin, Iza. 2007. The Pursuit of the Perak Regalia: Islam, Law, and the Politics of Authority in the Colonial State. Law and Social Inquiry 32(3): 759-88.

Johnson, Timothy R. 2004. Oral Arguments and Decision Making on the United States Supreme Court. Albany: State University of New York Press.

Judge, Melanie, and Dee Smythe. Forthcoming. Striking Women: The Politics of Gender, Sexuality and the Law in South Africa. In C. Ashford \& A. Maine (eds.), Research Handbook on Gender, Sexuality and Law. Cheltenham, UK and Northampton, MA, USA: Edward Elgar Publishing.

Kalman, Laura. 1990. Abe Fortas: A Biography. New Haven, CT: Yale University Press.

Kapiszewski, Diana, Gordon Silverstein, and Robert Kagan. 2013. Consequential Courts: Judicial Roles in Global Perspective. New York: Cambridge University Press.

Kaplan, Thomas. 2019. Federal Courts, Running Out of Money, Brace for Shutdown's Pain. The New York Times. January 18. www.nytimes.com/2019/01/18/us/politics/courts-money-government-shutdown.html Accessed January 22, 2019.

Kenney, Sally. 1994. For Her Own Protection. Ann Arbor: University of Michigan Press.

Kenney, Sally. 2013. Gender and Justice: Why Women in the Judiciary Really Matter. New York: Routledge.

Kenney, Sally, William Reisinger, and John Reitz (eds). 1999. Constitutional Dialogues in Comparative Perspective. New York: Palgrave Macmillan.

Knight, Jack, and Lee Epstein. 1996. The Norm of Stare Decisis. American Journal of Political Science 40(4): 1018-35.

Kretsedemas, Phillip. 2012. The Immigration Crucible: Transforming Race, Nation and the Limits of the Law. New York: Columbia University Press.

Latour, Bruno. 2009. The Making of Law: An Ethnography of the Conseil d'Etat. London: Polity Press.

Lokaneeta, Jinee. 2018. Rule of Law, Violence and Exception: Deciphering the Indian State in the Thangjam Manorama Inquiry Report. Law, Culture and the Humanities. DOI 10.1177/1743872118761349.

Massoud, Mark. 2013. Law's Fragile State. New York: Cambridge University Press.

Melnick, R. Shep. 1994. Between the Lines: Interpreting Welfare Rights. Washington, DC: Brookings Institution.

Mertz, Elizabeth. 2007. The Language of Law School: Learning to "Think Like a Lawyer." Chicago: University of Chicago Press.

Metcalf, Jacob, and Kate Crawford. 2016. Where Are Human Subjects in Big Data Research? The Emerging Ethics Divide. Big Data and Society January-June: 1-14.

Michel, Verónica, and Kathryn Sikkink. 2013. Human Rights Prosecutions and the Participation Rights of Victims in Latin America. Law and Society Review 47(4): 873-907.

Mishra, Pankaj. 2019. The Malign Incompetence of the British Ruling Class. The New York Times. January 17. www.nytimes.com/2019/01/17/opinion/sunday/brexit-ireland-empire.html Accessed January 18, 2019.

Moustafa, Tamir. 2003. Law versus the State: The Judicialization of Politics in Egypt. Law and Social Inquiry 28(4): 883-930.

National Science Foundation (NSF) n.d. Dissemination and Sharing of Research Results. www.nsf.gov/bfa/ dias/policy/dmp.jsp Accessed November 26, 2018.

O’Donnell, Guillermo. 1998. Horizontal Accountability and New Polyarchies. Journal of Democracy 9(3): $112-26$.

O’Donnell, Guillermo. 2001. Democracy, Law, and Comparative Politics. Studies in Comparative International Development 36(1): 7-36.

Pasquale, Frank. 2015. The Black Box Society. Cambridge, MA: Harvard University Press.

Remiche, Adélaïde. 2015. When Judging Is Power: A Gender Perspective on the French and American Judiciaries. Journal of Law and Courts 3(1) (03/01; 2018/11): 95-114.

Richland, Justin B. 2005. "What are you going to do with the village's knowledge?" Talking Tradition, Talking Law in Hopi Tribal Court. Law and Society Review 39(2): 235-72.

Riles, Annelise. 2006. Documents: Artifacts of Modern Knowledge. Ann Arbor: University of Michigan Press.

Ruppert, Evelyn. 2015. Doing the Transparent State: Open Government Data as Performance indicators." In Richard Rottenburg, Sally E. Merry, Sung-joon Park, Johanna Mugler, eds, The World of Indicators: The Making of Governmental Knowledge through Quantification. Cambridge, MA: Cambridge University Press, $127-50$. 
Santora, Marc. 2017. Amid Growing Uproar, Poland to Remove 27 Supreme Court Justices. The New York Times July 3. www.nytimes.com/2018/07/03/world/europe/poland-supreme-court-judiciary.html Accessed January 14, 2019.

Schuck, Peter H. 1987. Agent Orange on Trial: Mass Toxic Disasters in the Courts. Cambridge, MA: Belknap Press of Harvard University Press.

Shapiro, M.M. 1981. Courts, a Comparative and Political Analysis. Chicago: University of Chicago Press.

Silbey, Susan S. 2005. After Legal Consciousness. Annual Review of Law and Social Science. 323-68. doi: 10.1146/annurev.lawsocsci.1.041604.115938.

Silbey, Susan S., and Ayn Cavicchi. 2005. The Common Place of Law: Transforming Matters of Concern into the Objects of Everyday Life. In Bruno Latour and Peter Weibel, eds, Making Things Public: Atmospheres of Democracy. Cambridge, MA: The MIT Press, 556-66.

Soennecken, Dagmar. 2016. The Paradox of Docket Control: Empowering Judges, Frustrating Refugees. Law and Policy 38(4) (October 2016) 304-27. http://dx.doi.org/10.1111/lapo.12062.

Sterett, Susan. 1997. Creating Constitutionalism? The Politics of Legal Expertise and Administrative Law in England and Wales. Ann Arbor: University of Michigan Press.

Sterett, Susan. 2016. Legal Mobilization and Juridification: Migration as a Central Case. Law and Policy 38(4): 273-9.

Sterett, Susan. 2018. Data Access as Regulation. American Behavioral Scientist. https://doi.org/10.1177/000276421 8797383.

Walker, Lee D. 2016. A Multi-Level Explanation of Mass Support for the Judiciary. Justice System Journal 32(3): 194-210.

Wines, Michael. 2019. Court Blocks Trump Administration from Asking about Citizenship in Census. The New York Times January 15. www.nytimes.com/2019/01/15/us/census-citizenship-question.html Accessed January $22,2019$. 